\title{
Political Change in the Digital Age: The Fragility and Promise of Online Organizing
}

\section{Citation}

Bruce Etling, Robert Faris and John Palfrey, Political Change in the Digital Age: The Fragility and Promise of Online Organizing, SAIS Review, Summer-Fall 2010, at 37.

\section{Published Version}

http://muse.jhu.edu/journals/sais_review/summary/v030/30.2.etling.html

\section{Permanent link}

http://nrs.harvard.edu/urn-3:HUL.InstRepos:4609956

\section{Terms of Use}

This article was downloaded from Harvard University's DASH repository, and is made available under the terms and conditions applicable to Other Posted Material, as set forth at http:// nrs.harvard.edu/urn-3:HUL.InstRepos:dash.current.terms-of-use\#LAA

\section{Share Your Story}

The Harvard community has made this article openly available.

Please share how this access benefits you. Submit a story.

Accessibility 

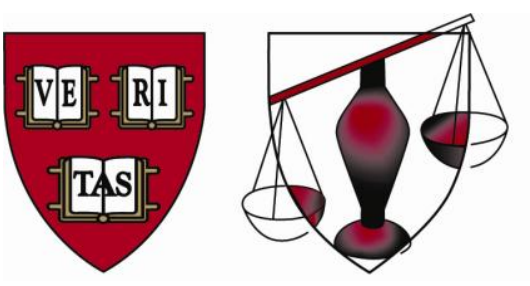

Berkman

The Berkman Center for Internet \& Society at Harvard University

\title{
Political Change in the Digital Age: The Fragility and Promise of Online Organizing
}

By Bruce Etling, Robert Faris and John Palfrey

\begin{abstract}
We conclude that policymakers and scholars that have been most optimistic about the impact of digital tools have over-emphasized the role of information, specifically access to alternative and independent sources of information and unfiltered access to the Internet. We argue, in contrast, that more attention should be paid to the means of overcoming the difficulties of online organization in the face of authoritarian governments in an increasingly digital geopolitical environment.
\end{abstract}

Copyright (C) 2010 The Johns Hopkins University Press. This article first appeared in SAIS Review, Volume 30, Issue 2, December, 2010, pages 37-49. 


\section{Introduction}

In June 2010, 28-year-old Khaled Said was approached by police officers, presumably for a bribe, and beaten to death when he refused to give them money. A witness captured the image of the victim's bloodied face as proof of police brutality and operation outside the law. The image was widely circulated, and led to weeks of newspaper headlines and protests. The officers were later charged with illegal arrest, torture and excessive force, a rarity in Egypt. Human rights activists argue that Said's case, and the popular outrage it generated, could be a turning point in their long campaign against police torture.

On April 6 ${ }^{\text {th }}, 2008$, the usually bustling markets and congested streets of Cairo fell silent. A general strike organized against President Hosni Mubarak and his government by young activists using Facebook, matched with a textile workers' walkout over low wages and soaring prices, became one of the most prominent protests in Egypt in years. What kept this event from becoming a successful example of online organization was the swift arrest of the organizers by the Egyptian government, who were able to easily track them down via their digital footprints. The public release of one of the organizers from prison, 27-year-old Israa Abdel Fattah, was widely distributed on YouTube. Her tearful run into her parents' arms and public promise to no longer organize such events relayed the regime's message clearly: it still has significant tools of repression at its disposal, and is not afraid to use them. A similar effort a year later fell flat, in large part due to the arrest of hundreds of potential protesters and organizers by the police before the event.

These two events illustrate both the potential impact and limitations of digital tools on social and political change. Examples similar to these are taking place daily around the world. In this paper, we discuss the possible impact of digital technologies in authoritarian and semiauthoritarian regimes, and distinguish between the role these tools play in facilitating the flow of information, such as the photograph of Khaled Said, and in offering digital tools for social organizing by activist groups, for example linking together individuals via Facebook. While information and organizing are inextricably linked-photographs and videos play an important and growing role in empowering and motivating social activists-it is helpful to consider them separately as the use of technology entails different opportunities and challenges for each.

The spread of information has thrived in a decentralized digital environment despite the efforts of many governments. Decentralized social organization is a much more challenging proposition. We argue that the continued ability of authoritarian states to neutralize hierarchical civil society organizations (CSOs) implies a larger role for political change via other types of decentralized and bottom-up social action.

Political change in consolidated democracies is driven by organizations with strong networks. Political change in authoritarian regimes is more likely to be enabled by more decentralized associations with loose networks.

We conclude that policy makers and scholars that have been most optimistic about the impact of digital tools have over-emphasized the role of information, specifically access to 
alternative and independent sources of information and unfiltered access to the Internet. We argue, in contrast, that more attention should be paid to the means of overcoming the difficulties of online organization in the face of authoritarian governments in an increasingly digital geopolitical environment.

\section{Digital Technologies, Information and Political Transitions}

Access to information through a vibrant media system has long been recognized as an essential element in well-functioning democracies. Free access to information and a free press serve as a check on government, aid in transparency, reduce corruption, allow for debate and criticism of government decisions, and provide citizens with an input into political processes between elections. Ideally, broad access to information fosters public debate of issues of political salience, and allows all sides in those debates to be heard. Political scientists and media scholars have noted a shift towards greater citizen participation in democracy and influence in governmental decision-making with increased access to information.

The Internet also allows new voices to enter the debate by reducing the influence of gatekeepers and by permitting the rise of citizen journalists to engage in previously expensive journalistic, transparency, or fact-checking endeavors. ${ }^{2}$ In authoritarian regimes, bloggers, online forums and other forms of new media provide alternative sources of news and information. This has reduced government control over information, particularly in those states that have exerted controls over traditional media organizations.

Because user-generated and virally shared information is so effective at uncovering corruption and allowing criticism of government policies, it is feared by authoritarian leaders that otherwise have a lock on the media, policy, and politics. More voices, on more alternative platforms, allow citizens to criticize government, leaders, policies, and even the system of government itself, whether the target of the criticism is the rule of the clerics in Iran or the communist party in China. In fact, the Internet may be the only avenue left for citizens in authoritarian regimes to influence government, fight corruption, or defend their rights, since local and national officials are often appointed by the central government and more concerned with pleasing Moscow or Beijing than occupying themselves with the demands of citizens. An apt illustration is the YouTube plea by Russian police Major Alexei Dymovsky to President Medvedev and fellow officers to fight corruption among the widelydespised police. ${ }^{3}$ Although this brazen public act led to his arrest, Major Dymovsky was eventually released, the charges were dropped, and several senior Interior Ministry officials were fired as result of this incident and other similar protests by car owners against the police and Russian authorities.

\footnotetext{
${ }^{1}$ Michael Schudson, The Good Citizen: A History of American Civic Life (New York: Free Press, 2008); and John Keane, The Life and Death of Democracy (New York: W.W. Norton \& Company, 2009). Schudson uses the term 'monitorial citizen.' Keane offers a related framing in his description of 'monitory democracy.'

2 See the work of the Media Re:Public project at http://cyber.law.harvard.edu/pubrelease/mediarepublic for a survey of major issues associated with the rise of new media.

3 Video available at http:/ www.youtube.com/watch?v=R4vB2a15dOU\&feature=PlayList\&p=6EA5F7C6284CDCC7\&playnext= $\underline{1 \text { \&index }=38}$ (accessed July 23, 2010).
} 
But perhaps the best illustration of the threat this information poses to authoritarian governments is their reaction to it. States have made a number of efforts to rein in Internet speech, including Internet filtering, cyber-attacks, informal threats and intimidation, new and expanded legal tools for limiting online speech, and Internet surveillance. Currently, there are several dozen countries that filter the Internet to various degrees. China and Iran are among the most aggressive in limiting access to information online. Each employs a broad mix of policies in an attempt to police online speech. They are joined by a growing set of countries that are applying stringent online media controls, including Burma, Tunisia, Uzbekistan and Vietnam, among others. ${ }^{4}$

Despite the best efforts of authoritarian governments, increased freedom of expression enabled by the decentralized and difficult-to-control Internet has had a palpable impact on political processes. However, there is much more to the picture.

\section{Information, Organizing and Areas of Contestation}

In this section we describe a simple analytical framework that describes the interaction among civil society organizations (CSOs), media and governments in different types of regimes. There are numerous examples of authoritarian states that seek to curtail the influence of non-governmental actors by controlling access to media and information and by limiting the formation and activities of civic organizations. The transition towards greater democracy is associated with expanding free speech and rights of assembly. In both instances, progress implies the devolution of power towards non-governmental actors, increased civil liberties and concomitant restraints on government action.

Many countries are at a stage in which individuals and civil society groups struggle against government for access to alternative sources of information and for the right to constitute non-governmental organizations, including Egypt, Kazakhstan, Thailand and Zimbabwe. This struggle over the right to speech and association corresponds to the situation in countries described by political scientists as thin or illiberal democracies. ${ }^{5}$

\footnotetext{
4 These online content restriction practices are well documented. See Ronald Deibert, John Palfrey, Rafal Rohozinski and Jonathan Zittrain, Access Controlled: The Shaping of Power, Rights, and Rule in Cyberspace (Cambridge: MIT Press, 2010); and John Palfrey, Jonathan Zittrain, Ron Deibert and Rafal Rohozinski, Access Denied: The Practice and Policy of Global Internet Filtering (Cambridge: MIT Press, 2008); additional research is available at http://opennet.net/.

${ }^{5}$ Fareed Zakaria, "The Rise of Illiberal Democracy," Foreign Affairs, November/December $1997<$ http://www.foreignaffairs.org/19971101 faessay3809/fareed-zakaria/...democracy.html> (accessed March 27, 2008); Larry Diamond, The Spirit of Democracy: The Struggle to Build Free Societies Throughout the World, New York, NY: Times Books, 2008).
} 


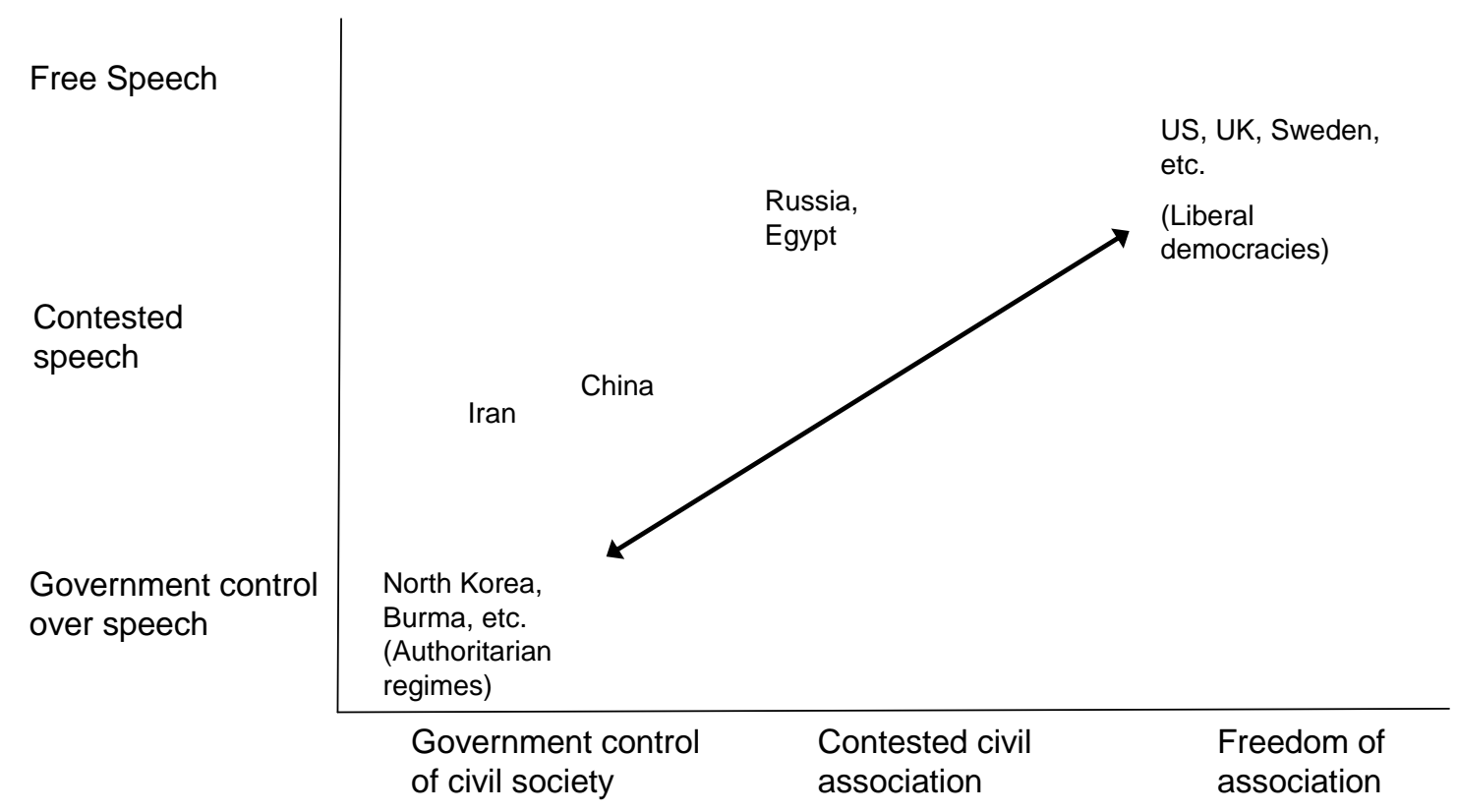

Figure 1: Freedom of Speech and Association in Different Political Regimes

Liberal democracies are in part defined by the strong protections they offer for the rights of speech and association. It is here that we see the development of a robust and competitive media landscape and the formation of a strong and diverse set of civil society groups. In Figure 1, movements towards the upper-right entail a shift in the focus of contestation from civil actors asserting their rights against resistant governments to a competition among nongovernmental actors for influence in social, economic and political processes.

Improved access to information leads to an asymmetry in the evolution of information and civil society organizations; several countries that have more open media ecosystems by virtue of Internet and mobile phone communication still have not seen the same gains in the development of civil society organizations. There are several examples that fall within this category, including Egypt and Russia. There are no examples we know of where the converse is true: a country in which the right of association surpasses the right to freedom of speech. This is notable in that the interaction of government and civil society groups parallels the many complex processes associated with political reform and democratic transition, and as such, the development of civil society seems to serve as a useful indicator for the level of democratic governance.

A major part of the democratic transition is the fight among civil society for the right to engage in open and active political life. In those countries that succeed in consolidating democracy, there is a political shift from governments battling the formation of civil society organizations to the battle among these organizations for political influence. To understand the role of digital tools on democratic processes, we must better understand the impact of the use of these tools on the composition and role of civil society. 


\section{Mobs, Movements and Organizations}

Popular protests, social movements, and civil society organizations represent different manifestations of social action and advocacy groups. It seems natural that the Internet benefits these bottom-up, grass roots groups since, as Yochai Benkler and others have theorized, the Internet lowers the costs of participation for citizens, increases the autonomy of the individual, gives individuals greater choice in the content they consume and the political issues they find most salient, and dilutes the power of traditional elites, gatekeepers, and institutions. ${ }^{6}$ The affordances of digital technologies influence the formation and activities of civil society groups, which we divide into three categories: mobs, ${ }^{7}$ movements and civil society organizations (CSOs). ${ }^{8}$

\section{Mobs and Episodic Popular Protests}

While mass popular protests are by no means a new phenomenon, several examples suggest that digital tools facilitate their formation. Howard Rheingold argues that new technologies allow people to act in concert-in smart mobs-even when they do not know each other, and in ways they could not previously conceive, because the devices they use have both communication and computing capabilities. Two early examples of cell phone-enabled smart mobs are the 1999 anti-globalization street protests in Seattle and the massive antiEstrada protests in the Philippines that forced the President from office. ${ }^{9}$ A more recent example is the No Mas FARC protest, in which a young Colombian was able to successfully mobilize 13 million people to join in protests in Colombia and several other countries using Facebook. This was an important event given the prior reluctance of many to publicly denounce the FARC and fear of reprisals. In general, online mobilization of the 'mob' sort is episodic and more likely to be spontaneous.

\section{Social Movements}

Charles Tilly describes social movement as campaigns with a clear, long-term objective to 'right a wrong' that often has been inflicted on a well-specified population. Social movements consist of multiple means-ended actions, whose goal is to correct the wrong suffered. Tilly describes the actions of social movements as symbolic, cumulative, and indirect. Unlike flash mobs or smart mobs, social movements hold out almost no hope that any single event will achieve their stated objective of ending an injustice or persuading authorities to enact a needed law. ${ }^{10}$ While social movements operate for a longer period of

\footnotetext{
${ }^{6}$ Yochai Benkler, The Wealth of Networks: How Social Production Transforms Markets and Freedom (New Haven: Yale University Press, 2006).

${ }^{7}$ We use mobs, flash mobs and smart mobs interchangeably in this paper to reflect online organized popular protests.

${ }^{8}$ Clay Shirky, Here Comes Everybody: The Power of Organizing Without Organizations (New York: Penguin Press, 2008).

${ }^{9}$ Howard Rheingold, Smart Mobs: The Next Social Revolution (Cambridge: Perseus Publishing, 2003).

${ }^{10}$ Charles Tilly, "Social movements and (all sorts of) other political interactions-local, national, and international-including identities," Theory and Society 27 (1998)
} 


\begin{tabular}{|c|c|c|}
\hline & & \\
\hline $\begin{array}{l}\text { Government control } \\
\text { of civil society }\end{array}$ & $\begin{array}{l}\text { Contested civil } \\
\text { association }\end{array}$ & $\begin{array}{l}\text { Freedom of } \\
\text { association }\end{array}$ \\
\hline
\end{tabular}

Figure 2: Three Models of Social Organizing - Mobs, Movements and CSOs

time than mobs, they are rarely permanent, and frequently break up when they achieve their objectives, although sometimes they morph into persistent civil society institutions or political parties, if favorable political and regulatory conditions exist.

A leading practitioner and scholar in the field, Marshall Ganz, ${ }^{11}$ argues that social movements emerge as a result of the efforts of purposeful actors (individuals and organizations) to form new relationships, assert new public values, and mobilize political, economic, and cultural power to translate these values into action. ${ }^{12}$ They differ from fashions, styles, or fads (viral or otherwise) in that they are collective, strategic and organized. ${ }^{13}$ They differ from interest groups in that they focus not so much on allocating goods as on redefining them. ${ }^{14}$ Initiated in response to conditions that adherents deem intolerable, social movement actors make moral claims based on new personal identities, collective identities, and public action. ${ }^{15}$

A much studied and often-cited example of a successful social movement is the civil rights movement in the United States during the 1960s. More recently, Juan Cole and others have

\footnotetext{
11 Marshall Ganz, Presentation given at Berkman Center for Internet \& Society event "Building a Framework for the study of the Internet \& Democracy," 2008, Budapest, Hungary.

12 Thomas Rochon, Culture Moves: Ideas, Activism, and Changing Values, (Princeton: Princeton University Press, 1998).

${ }^{13}$ Gary T. Max and Doug McAdam, "Collective Behavior in Oppositional Settings: the Emerging Social Movement" in Collective Behavior and Social Movements (Englewood Cliffs: Prentice Hall).

${ }^{14}$ Mario Diani, "The Concept of Social Movement", in Readings in Contemporary Political Sociology, edited by Kate Nash, (New York: Blackwell Publishing, 2000), 158-176.

15 Eric Foner, The Story of American Freedom, (New York: W. W. Norton, 1998); Theda Skocpol, Marshall Ganz, and Ziad Munson, "A Nation of Organizers: The Institutional Origins of Civic Voluntarism in the United States", American Political Science Review, Vol. 94, No. 3 (Sep., 2000), pp. 527-546; Marshall Ganz, "Left Behind”: Social Movements, Parties, and the Politics of Reform" Unpublished Paper, presented at the Annual Meeting of the American Sociological Association, August 2006, Montreal.
} 
argued persuasively that the Green Movement in Iran is best viewed as a social movement. ${ }^{16}$ It is hard to imagine a successful social movement today that would not seek to leverage the Internet and social media to achieve their short and long term goals. President Obama's election campaign may be seen ultimately as one of the first successful Internet-driven social movements.

Social movements differ from mobs in a number of ways. First, they are focused on a single, long-term goal. Second, they may take years to achieve that goal, so they are far more persistent and focused than smart mobs or one off political protests. Third, they will have more identifiable leadership to drive the agenda and mobilize participants. Fourth, they will tend to have more developed organizational structures.

\section{Civil Society Organizations}

There is a broad consensus among democracy scholars that a vibrant civil society is a critical component of consolidated, liberal democracies. Civil society can be defined as the engagement of citizens in activities as part of formal groups and associations, which exist and operate outside the government. Examples include trade unions, professional associations, church groups, student organizations, and many others. As Tocqueville famously observed in $19^{\text {th }}$ century America, the social, commercial, political, religious and all other manner of associations, large and small, trivial and serious, in which Americans constantly joined and participated were a cornerstone of American democracy. ${ }^{17}$ More recently, Robert Putnam has decried the drop in civic participation in the US, because he believes that the dense networks of civic engagement that these groups create build interpersonal trust and social capital among members, which makes cooperation for mutual benefit in other areas of social and political life more likely. ${ }^{18}$ This social capital, he further argues, bolsters the performance of both the polity and the economy: "Strong society, strong economy; strong society, strong state."19

Samuel Huntington has noted the important role of CSOs in the 'third wave' of democratic transitions, from trade unions and the Solidarity movement in Poland, to policy changes by the Catholic Church during the Second Vatican Council. ${ }^{20}$ Larry Diamond has also observed that in most democratic transitions, civil society played a crucial role in mobilizing and articulating public pressure for democratic change. He writes that although there is variation in each democratic transition, a substantial combination of civil society actors-including trade unions, student organizations, churches, professional associations, women's groups, human rights organizations, ethnic associations, underground media, and various groups of intellectuals, journalists, merchants, and peasants—combined to coerce or force the exit of

\footnotetext{
${ }^{16}$ Juan Cole, “The Greens are a Movement, Not a Coup,” Informed Comment, http://www.juancole.com/2010/06/the-greens-are-a-movement-not-a-coup.html (accessed July 16, 2010)

17 Alexis de Tocqueville, Democracy in America, translated, edited and with an introduction by Harvey $\mathrm{C}$. Mansfield and Delba Winthrop (Chicago: University of Chicago Press, 2000) 489.

${ }^{18}$ Robert Putnam, "Bowling Alone: America's Declining Social Capital," Journal of Democracy 6.1 (1995)

${ }^{19}$ Robert Putnam, Making Democracy Work: Civic Traditions in Modern Italy (Princeton, NJ: Princeton University Press, 1993).

${ }^{20}$ Samuel P. Huntington, The Third Wave: Democratization in the Late Twentieth Century (Norman, OK: University of Oklahoma Press, 1991) 26.
} 
authoritarian leaders. ${ }^{21}$ Scholars of this bent argue that precisely because civil society exists outside of the state, they can more easily mobilize resistance against authoritarian regimes. ${ }^{22}$

The primary attribute that sets CSOs apart from mobs and social movements is their permanence - or at least expected permanence. They also have all the trappings of any other traditional offline institution: leadership, staff, advisory boards, office space, and today, an online presence and social media strategy. While all of these organizing models may entail a mix of bottom-up and top-down hierarchical structures, CSOs tend to have a higher degree of top-down organization and mobs the least.

While we find it is analytically useful to classify online organizing in the taxonomy described above, these are not hard and fast categories. There are examples of smart mobs that become social movements and movements that develop into more permanent civil society organizations. An interesting example is MoveOn.org. Started by two Silicon Valley entrepreneurs, Joan Wade and Wes Boyd, MoveOn.org began as an online petition to protest the impeachment of President Bill Clinton. It has since evolved into a multi-issue organization that today is closer to a political umbrella institution that advocates progressive policy issues, as well as a political action committee, which collects and distributes political donations to candidates it supports.

\section{Online Organizing and Contentious Politics}

Flash mobs, social movements and CSOs in consolidated democracies can use digital tools to motivate participants, organize protest actions, gain new adherents, capture attention of the mainstream media, and otherwise exert political influence, thanks in large part to strong protections for freedom of speech and association, and the high levels of Internet and cell phone penetration. It is this type of environment that allowed the Obama campaign to develop a highly sophisticated online organizing strategy that combined top-down hierarchical organizing with the energy and enthusiasm of bottom-up emergent structures.

The Internet and digital tools notwithstanding, hierarchical organizations with strong networks - the mainstay of civil society in consolidated democracies-are not a viable option in authoritarian states. CSOs, whose offline activities are already highly regimented and watched by the state, are not exempt from the same scrutiny and restrictions in their use of digital tools. CSOs are easy targets; their staff can be harassed or arrested and registration permits can be revoked if they stray outside the lines of accepted political organization. The difficulty faced by foreign and domestic CSOs in Russia that deal with politically contentious issues, including human rights and free media, is instructive.

The 2007 Burma protests occupy the grey area between a flash mob and a social movement. Instigated by rising gas prices, protests escalated and encompassed thousands from across society, notably including a large number of monks. Cell phones and video cameras played a critical role in reporting the events to the world. This reporting by citizen journalists and activists undoubtedly fed a sense of international support and would have strengthened the

${ }^{21}$ Diamond, The Spirit of Democracy.

${ }^{22}$ Michael Foley and Bob Edwards: “The Paradox of Civil Society” Journal of Democracy 7(3) 1996. 
resolve of protestors. There is little evidence to suggest that digital tools were widely used to organize the protests.

The experiences from the Green Revolution in Iran follow a similar pattern. ${ }^{23}$ Although there was a great deal of excitement about the role of Twitter in Iran after the presidential election, more recent evidence indicates that Twitter conversation about the Iranian protests occurred mostly among those in the West, and most likely was not used by Iranians to organize. Instead, Twitter and other social media were used to report protest events as they unfolded, replacing the foreign press and also creating international support for the movement. The greatest impact of the Internet on the Green Movement may have been the YouTube video that documented the death of Neda Agha-Sultan. This likely served as a key 'mobilizing event' that spurred on the social movement by offering a rallying cry and a common narrative among its participants.

Efforts at digital organizing in Iran do not appear to have been effective. In the run-up to the disputed election, the Mousavi campaign sought to use Facebook to rally supporters. The government responded by simply blocking access to Facebook. Online communities that congregate at a single URL are easily dismantled; organizations that rely on a centralized nodes and hierarchical structures are trivial to break up.

The activities of social movements will gain influence only to the extent that they are able to avoid the scrutiny and controls of the state. The use of digital tools does not lessen the ability of the state to crack down on leaders and disrupt social organizing. In fact, the ability of the state to carry out surveillance of online networks may make these communities more vulnerable than their offline counterparts. Although they differ in their approach to online speech, the attitude of states like Iran, China and Russia towards real political competition is unanimous: it is treated as a threat, and those political groups that are seen as a significant threat to the regime are vigorously resisted, if not quickly eliminated or marginalized. In Russia, the democratic opposition has an active presence in the blogosphere and other social media, but only marginalized opposition political parties are allowed to participate in elections, and their minority status is ensured through electoral legislation and other coercive methods. In Egypt, the Muslim Brotherhood is prohibited from participating in elections, although their online presence is tolerated along with other opposition groups.

A possible alternative for CSOs and social movements in hostile online environments is to operate under the veil of anonymity. However, anonymity diminishes the effectiveness of the very factors that facilitate effective social and political organizing identified by Tilly, Ganz and others: leadership and displays of unity and commitment. It is therefore not surprising that there are no examples of influential political movements comprised of anonymous participants. These meager alternatives greatly diminish the potential for online organizing in states that are intent on preventing such activity.

Smart mobs, however, particularly where they emerge organically and take governments by surprise, may be possible in all but perhaps the most restrictive authoritarian regimes. In a

\footnotetext{
${ }^{23}$ John Palfrey, Bruce Etling and Robert Faris, "Reading Twitter in Tehran?: Why the Real Revolution is on the Streets—and Offline." The Washington Post, June 21, 2009, available at: http:/ /www.washingtonpost.com/wpdyn/content/article/2009/06/19/AR2009061901598.html (accessed July 23, 2010).
} 
few cases, the ability of a mob to quickly overwhelm unprepared governments has been successful. The cell phone-aided resignation of Estrada in the Philippines is perhaps the best example of political change that was preceded by mass protests; other offline examples include the quick fall of the governments in Serbia and Kyrgyzstan. The result of other protests, such as the anti-FARC protests, is less clear; although the large turnout may have had an impact on the positions and long-term strategies of both FARC and the Colombian government. In other cases, short-lived protests may induce little or no change. The failure of the 2007 protests to topple the regime in Burma is an apt example.

\section{The Uncertain Future of Digital Organizing}

The relative success of decentralized digital reporting has supported the monitorial citizen and improved transparency and accountability in all but the most digitally repressed states. A logical consequence of this in closed regimes is a greater sense of outrage over corruption and political malfeasance and a greater appetite for social action. As more citizens gain access to the Internet, membership in latent social and political communities will grow: a larger cohort of potential political activists to be triggered by the next manifestation of social injustice caught on a cell phone or video camera. When combined with a continued restraint on organized social action, this suggests that we may see an upturn in bottom-up spontaneous protests focusing on specific high-profile issues, local events and the most visible abuses of power. Should this prove true, there are a number of possible outcomes. We could see authoritarian governments that are more responsive to the expressed needs of their people with moderate improvements in policy or governance. Other possible outcomes include more rapid containments of civil actions or a more frequent turnover in governments. We would almost certainly see increased efforts to contain information flows and to preemptively disarm, or co-opt, grass roots political action.

The prospect of a proliferation of political flash mobs is not an entirely rosy one. As Rheingold and others have observed, digital technologies can be used just as easily by those with nefarious intentions as those acting in the public interest. Poorly organized mass actions are highly unpredictable and easily manipulated. In Kenya, for example, text messages were used to direct attacks against minorities during a period of post-election violence in $2007 .^{24}$

A challenge for improving the prospects of digitally-assisted political reform in closed societies that must rely on decentralized networks is to adapt, emulate and transfer the benefits of highly organized civil society groups, as bottom-up decentralized organizing is more likely to survive in repressive regimes. Compared to more tightly structured hierarchical organizations, flash mobs do not have the same level of leadership, discipline, long-term planning and ability to incorporate prior experience. In other words, flash mobs do not deliberate; they do not debate the alternatives and select pragmatic and well informed strategic approaches.

\footnotetext{
${ }^{24}$ Josh Goldstein and Juliana Rotich, "Digitally Networked Technology in Kenya's 2007-2008 Post-Election Crisis," Berkman Center Research Publication No. 2008-09, September 2008, available at: http://cyber.law.harvard.edu/publications/2008/Digitally Networked Technology Kenyas PostElection Crisis (accessed July 23, 2010).
} 
An interesting prospect is that digital communities will emerge to serve as venues for deliberation and to provide collective leadership for smart mobs. Currently, the closest manifestation to such a decentralized deliberative body is the blogosphere. The Egyptian blogosphere is a possible example. It is comprised almost entirely by those in opposition to the government, and includes a range of opposition voices, including secular-minded bloggers connected to the Kefaya movement, more conservative Muslim Brotherhood bloggers, and those dedicated to stopping torture and abuse by police. ${ }^{25}$ Many of these communities exist both online and off, some loosely affiliated and some with tighter networks. These groups serve as ideal outlets for sharing stories and exchanging visions of change. These online communities in Egypt promote reform and serve as a rallying point when key events take place such as the arrest of bloggers and activists. Reform movements may be pushed forward by ideas and reports of injustice, such as the treatment of Khaled Said, but they are sustained by communities, such as these loosely affiliated online communities in Egypt. It is an open question whether these communities can emerge as coherent social movements while remaining decentralized bottom-up institutions.

The Russian drivers' movement offers another example where online organizing is contributing to a social movement, but also shows that change will most likely be limited to improved 'responsive authoritarianism' instead of fundamental political change. The core of this movement includes car clubs, such as the Federation of Car Owners, that organize largely online. They have organized successful protests against increased taxes, traffic police corruption, police scandals, and a series of fatal auto accidents involving wealthy and politically connected drivers who often escape prosecution for their crimes. Indeed, there have been a number of cases where the victims are blamed, despite video or witness evidence to the contrary. One famous incident involved a senior executive of a large Russian oil company, which spawned a video appeal by a popular rap musician that had 600,000 hits in just a few days. Video and witness evidence are gathered, shared widely on YouTube, debated in blogs and on other online forums, and eventually picked up by mainstream media where they generate further outrage. These protest events appear to have contributed (or at a minimum, hastened the president's decision) to fire 16 high-level police officers and order a restructuring of the Interior Ministry, one of Russia's 'power ministries.' Following the 'horns of wrath' caravan protests in a number of Russian cities, drivers also successfully halted a doubling of taxes on car owners. While this type of change is limited, and will likely not lead to a change in regime type or greater democratization in Russia, it is significant in a country where there are few remaining opportunities for bottom up political action, and the Internet is a fundamental part of it. ${ }^{26}$

\footnotetext{
25 Bruce Etling, John Kelly, Robert Faris and John Palfrey, "Mapping the Arabic Blogosphere: Politics, Culture and Dissent" Berkman Center Research Publication No. 2009-06, available at: http://cyber.law.harvard.edu/publications/2009/Mapping the Arabic Blogosphere (accessed July 23, 2010).

${ }^{26}$ Henning Schroder, "Modern Times' Is there Movement in Russian Politics?” Russian Analytical Digest (No. 77) 26 April, 2010; Richard Boudreux, "Russian Revolution: Mad motorists protest by slowly circling Moscow," The Wall Street Journal, available at http://online.wsj.com/article/SB10001424052702304798204575183761361534460.html (accessed July 23, 2010); “Car Industry Expert says Russian Public Discontent 'Only Beginning to Rise”" Radio Free Europe/Radio Liberty, December 23, 2008, available at: http://www.rferl.org/content/Car Industry Expert Says Russian Public Discontent Only Beginning To

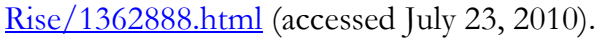


The Internet has an important role in increasing information sharing, access to alternative platforms, and allowing new voices to join political debates. The Internet will continue to serve these functions, even with state pushback, as activists devise ways around state online restrictions. Conditions that contribute to success are likely determined not by the given technological tool, but by human skill and facility in using the networks that are being mobilized. Further, those movements that are most successful appear to combine the best of 'classic' organizing tactics with the improvisation, or 'jazz,' that is enabled by new Internet tools; for example, constantly updated mobile mapping tools used by campaign volunteers that target swing voters in US elections, a classic campaign tactic made easier and more volunteer centric by technology. It is less clear how far online organizing and digital communities will be allowed to push states toward drastic political change and greater democratization, especially in states where offline restrictions to civic and political organization are severe. As scholars, we ought to focus our attention on the people involved and their competencies in using digitally-mediated tools to organize themselves and their fellow citizens, whether as flash mobs or through sustained social movements or organizations, rather than the flow of information as such. 